\title{
1 Crustal-scale listric geometry of the San Andreas Fault driven by lower crustal
}

\section{2 flow}

3 Authors: Haibin Yang ${ }^{1,2}$, Louis N. Moresi ${ }^{2,1}$, Mark Quigley ${ }^{1}$

4 Affiliation 1: School of Earth Sciences, University of Melbourne, Victoria, Australia

5 Affiliation 2: Research School of Earth Science, Australian National University, Canberra, Australia 6

7 Corresponding Author: Haibin Yang

8 Email: haibiny@student.unimelb.edu.au

9

10 This is a non-peer reviewed preprint submitted to EarthArXiv. 11

12 
The San Andreas Fault (SAF) is one of the dominant components of the transform boundary between the Pacific and the North American Plate. Although the fault is verticalto sub-vertical at shallow $(<10 \mathrm{~km})$ depth, it variably dips at angles of ca. $40-70^{\circ}$ to the southwest near the western Transverse Range and to the northeast in its southern segment at depth s of ca. 10-20 km, and thus can be described as having a listric geometry at the crustal scale. The mechanism controlling the fault dip direction variation at depth along SAF is not well understood. We utilize a 3D, finite element thermomechanical, viscoplastic model to simulate lithospheric deformation associated with the SAF. The Big Bend of the fault near the western Transverse Range is taken as a geometrical initial condition. Numerical experiments demonstrate that regional lower crust strength variation along the SAF strike is an important control on fault dip direction. For two blocks separated by transpressional faults, viscous lower crustal material moves from the high viscosity (strong) block to the lower viscosity (weak) lower crustal block. Fault-plane-normal flow in the viscous lower crust forces fault dip direction at brittle-ductile transitional depth to rotate in the flow direction. Geophysical data suggest that the Great Valley (eastern block) and south coast area (western block) have stronger lower crust than their opposing faultblocks and that the SAF dips towards the weaker block in both instances. Our self-consistent model also sheds light on the left-lateral

31 Garlock Fault, which intersects the right-lateral SAF in the western Transverse Range. To maintain a vertical dip in the shallow crust and structural-kinematic connectivity with the migrating fault zone at visco-elastic depths, the SAF may exhibit spatiotemporal transience

34 in upper crustal fault location and geometry over geological time scales, including strain zone widening and dispersions. This behavior is expected to have ramifications for SAF earthquake behaviors including rupture nucleation locations and segmentation and adds 
complexity to expectations that strain should localize on sub-vertical strike-slip faults with increasing fault maturity.

\section{Introduction}

In a triaxial stress system with orthogonal principal compressive stresses $\sigma 1>\sigma 2>$ $\sigma 3$, where $\sigma 1$ and $\sigma 3$ are horizontal and $\sigma 2$ is vertical, shear failure in intact rock is expected to occur on subvertical strike-slip faults oriented $\sim 30^{\circ}$ to $\sigma 1$ (Anderson, 1905). With pro-

44 gressive deformation, formed faults may grow and interact (Roy and Royden, 2000b; Yang et al., 2020) and kinematically and geometrically evolve in ways that may be influenced by lithospheric conditions such as crustal rheology (Roy and Royden, 2000b, a), changes in the strain field (Koons et al., 2003), and other lithospheric conditions (Bowman et al., 2003; Yang et al., 2018). Optimally-oriented sub-vertical strike-slip faults could be expected to maintain steeply dipping geometries over geological time-scales. However, some of the largest plate boundary strike-slip faults on Earth, e.g., San Andreas Fault in California, Alpine

51 Fault in New Zealand, Denali Fault in Alaska, have complicated geometries that include oppositely dipping and geometrically and kinematically distinct fault segments. The San Andreas Fault (SAF, Fig. 1) is a classical continental transform boundary between the Pacific and North American plates that accommodates $20-75 \%$ of the relative motion between the two plates $\left(\sim 50 \mathrm{~mm} \mathrm{yr}^{-1}\right)$ (Atwater and Stock, 1998; DeMets and Dixon, 1999; Meade and Hager, 2005) but varies in dip and geometry along strike and is thus a focus of this study.

Models for crustal deformation and earthquake rupture studies commonly simplify the 
59 segment dipping $\sim 50^{\circ}-70^{\circ}$ northeast in the southern end of the SAF has been revealed by

60 geodetic (Lindsey and Fialko, 2013), high-precision earthquake relocation (Lin et al., 2007)

61 and seismic reflection studies (Fuis et al., 2017), while the segment near the Big Bend was

62 found to dip $55^{\circ}-75^{\circ}$ southwest by the analysis of potential-field data (Fig. 1) (Fuis et al.,

63 2012). Recent earthquake hypocenter relocation studies show that the straight section to 64 the north of the Big Bend is steeply dipping (Kim et al., 2016).

A non-vertical strike-slip fault plane may be an inherited structure from previous moderately dipping fabrics in mid-lower crustal depth (Schulte-Pelkum et al., 2020), or caused by transpressional deformations with a large ratio $(>\sim 0.4)$ of normal to transcurrentdisplacement that drives fault rotation (Braun and Beaumont, 1995). In a transpressional stress regime, the Anderson theory of faulting predicts conjugate fault planes, but it is hard to discem which one is the master fault. Roy and Royden (2000b) found the minor faults adjacent to the subvertical strike-slip fault plane might have moderately dipping angles at the brittleductile depth, but it cannot explain geometry of the major fault like the SAF. The static solution of Anderson faulting theory neglects the long-term evolution of a fault and the depth dependent rheology in crust.

We use the numerical geodynamic modelling method to simulate the long-term behavior of the SAF and propose that the deep ductile deformation due to viscosity contrast between two fault-bounded blocks would affect shallow, brittle-fault kinematics. To test our hypothesis, regional geophysical observations are combined to examine the ductile strength in the lithosphere. Modelling results also shed light on secondary fault distributions associated with SAF, e.g., the Garlock fault intersecting the SAF near the Big Bend (Fig. 1). 
The particle-in-cell, finite-element, geodynamics code Underworld2 (Mansour et al.,

83 2020) (https://doi.org/10.5281/zenodo.1436039) is used to model the 3D thermo-mechani-

84 cal deformation in the SAF system (Moresi et al., 2007). Underworld2 solves the equations

85 for conservation of momentum and mass (incompressible material). The resulted velocity

86 field are coupled in temperature calculation with advection-diffusion equation. The Bous-

87 sinesq approximation is assumed for the equation of state.

We assume a power law dislocation creep to represent viscous flow. Drucker-Prager pressure-dependent yielding criteria is used for plastic deformation $\sigma_{\text {yield }}=P \tan \phi+C$, where $\sigma_{\text {yield }}$ is the maximum second deviatoric stress invariant, $\tan \phi$ is the friction coeffi-

91 cient and $C$ is the cohesion. Linear strain weakening of the friction coefficient (0.4-0.02) and cohesion (20-5 MPa) between plastic strains of 0.5 and 1.5 allows for strain localization.

93 Visco-plastic flow is modelled through an effective viscosity: $\eta_{v p}=\min \left(\eta, \frac{\sigma_{\text {yield }}}{2 \dot{\varepsilon}_{I I}}\right)$, where $\eta$ 94 is the viscosity represented by power law dislocation creep, and $\dot{\varepsilon}_{I I}$ is the second invariant 95 of strain rate. The viscosity is limited in the range between $10^{19} \mathrm{~Pa} \cdot \mathrm{s}$ and $10^{24} \mathrm{~Pa}$.s. Param96 eters used in the numerical experiments are listed in Table 1.

\section{Model description}

The model domain has total dimensions of $600 \times 300 \times 120 \mathrm{~km}$ with $144 \times 72 \times 48$ linear, quadrilateral elements (Fig. 1). The 120-km-thick model consists of a 30-km-thick crust and 101 a $90-\mathrm{km}$-thick mantle. Based on regional tectonic settings, the calculation domain is divided 102 into 3 tectonic blocks: the coast area (west of SAF), the Great Valley (east of SAF and north 
of the Garlock Fault), and the Sierra Nevada-Mojave (east of SAF) (Fig.1).Seismic surveys 104 show that the crustal thickness in the Coast Range (north of the coast area) to be $25-30 \mathrm{~km}$ 105 thick and 30-35 km in the other blocks (Mooney and Weaver, 1989; Jones et al., 1994; 106 Fliedneret al., 1996; Zhu and Kanamori, 2000). We set a constant value of $30 \mathrm{~km}$ for crustal 107 thickness and neglect lateral variations.

The crust is generally composed of felsic upper crust and mafic lower crust, but the 109 absence of mafic lower crust in the Mojave block is suggested by many seismic studies. A 110 Receiver function study found the $\mathrm{Vp} / \mathrm{Vs}$ ratio $<1.75$, indicating a felsic crust (Zhu and Kan111 amori, 2000). A seismic refraction survey (Fuis et al., 2001) detacted the seismic P wave 112 velocity in lower crust to be $6.3 \mathrm{~km} / \mathrm{s}$. This is unusually low: mafic lower crust generally has 113 a $\mathrm{P}$ wave velocity of $>6.5 \mathrm{~km} / \mathrm{s}$. which might be caused by removing of mafic lower crust 114 which can be linked to surface magmatism dated to early Miocene (ca. 22-24 Ma) (Glazner 115 et al., 2002). The southeast Sierra Nevada is also thought lost its crustal root (Jones et al., 116 1994; Fliedner et al., 1996), and the delamination is estimated to occur ca. 3.5 Ma, which is 117 evidenced by a pulsive emplacement of mafic potassic magmatism emplaced during 4-3 Ma 118 (Manley et al., 2000). Therefore, both the Mojave and Sierra Nevada block are designed in 119 our models to have no mafic lower crustal layer.

The model evolution time in our numerical experiments is $<4$ Myr. Because the relative 121 motion direction between the North American plate and Pacific plate shows no significant 122 changes since $8 \mathrm{Ma}$ (Atwater and Stock, 1998), the boundary conditions in our model do 123 not vary with model evolution. A constant shear velocity $(\mathrm{V} x)$ of $40 \mathrm{~mm} \mathrm{yr}^{-1}$ is applied on the 124 back plane $(y=300 \mathrm{~km})$ while the velocity in the front plane $(y=0 \mathrm{~km})$ is zero. Free slip 125 conditions are applied on the other boundaries. The initial condition for temperature field 
assumes half-space cooling model at 50 Myr. The resulting temperature at the Moho depth

$127(30 \mathrm{~km})$ is $550^{\circ} \mathrm{C}$ and surface heat flow is $50 \mathrm{~mW} \mathrm{~m} \mathrm{~m}^{-2}$.

The model includes a pre-defined weak zone with a Big Bend in the initial setup (Fig. 1). The 4-6 Ma near-fault block uplift of the San Emigdio Mountains along the Big Bend indicated from low-temperature thermochronology studies (Niemi et al., 2013) may be at131 tributed to the intensive transpressional strain near the Big Bend. In this case, we assume 132 that the Big Bend has formed when the model begins, though the exact time or mechanism 133 for the formation of Big Bend is debated (Popov et al., 2012; Niemi et al., 2013). The weak 134 zone is initially represented by materials with plastic strain of 2 , which is the upper limit of 135 the linear strain weakening, and the corresponding effective cohesion and friction coefficient 136 are $5 \mathrm{MPa}$ and 0.02 , respectively. This produces a weak faultas observed in regional stress 137 mapping and laboratory experiments (Zoback et al., 1987; Collettini et al., 2009; Lockner et 138 al., 2011). The fault plane is assumed to be vertical everywhere along the fault strike but 139 can deform with time. Fault is set to cut into $60 \mathrm{~km}$ deep to the mantle. A 50-km-wide and $14060-\mathrm{km}$-deep buffer zone is added to both ends of SAF to minimize artificial boundary effects. 141 The buffer zone has a relatively weak viscosity of $10^{20} \mathrm{~Pa} \cdot \mathrm{s}$; this value is applied to all ma142 terial particles that enter the buffer zone.

\section{Results}

A successful model should produce along-strike variations of the fault dipping direction

146 that are comparable with those detected in SAF, and other more features agree with obser147 vations in the SAF system. We have run series of models to test the influence of lower crust 
rheology and its heterogeneity distribution related to the composition or temperature heterogeneities. Here we show three main models: Model 1, Model 2, and Model 3. The crust in Model 1 has only one layer (the whole crust in all blocks is represented by quartzite rheol151 ogy). With all other parameters being equal, Model 2 has a mafic lower crust in the Great 152 Valley (20 km thick) and coast area (15 km thick). Model 1 and Model 2 show different 153 deformation patterns after 2 Myr evolution. In Model 2, the fault plane of the southern end $154(x=350-500 \mathrm{~km})$ evolves from initially vertical to dipping towards the Mojave block at $\sim 60$ 155 (Fig. 2a \& 2b). No moderately dipping fault as Model 2 form in Model 1. Moreover, a shear 156 157 band along the southern boundary of the Great Valley block occurs in Model 2 rather than Model 1 (Fig. 2a and 2b).

For Model 2, replacing the two-layered crust in Great Valley with only one layer of 159 160 quartzite rheology does not change the dipping pattern of Model 2, but a strong lower crust in the coast area is required to form a dipping fault toward the Mojave block. With these observations, the corollary is that lower crust viscosity contrast $\left(>10^{2} \mathrm{~Pa} \cdot \mathrm{s}\right)$ between two fault-separated blocks appears to determine the fault dip direction. We found that the strong lower crust material flows to the other fault-bounded block that has a weaker lower crust. In turn, the lower part of the upper crust overlying a weak lower crust thrust on top the footwall that has a strong lower crust. In this scenario, the fault dip direction is in accord with the relative motion between lower crust material across the fault.

Model 2 only produces the fault that is dipping to the Mojave block, and no dip direction variation along the strike. Model 3 is adapted from Model 2 and reduces mafic lower crust thickness in the central coast area $(x=250-400 \mathrm{~km})$ from $15 \mathrm{~km}$ to $5 \mathrm{~km}$ (Fig. 1). Moreover, to reflect lateral temperature heterogeneities in lithosphere, the initial temperature in the 
coast area follows the 30 Myr oceanic lithosphere geotherms, and that in Mojave block linearly increases from 30 Myr at the west boundary (the Big Bend) to 40 Myr at the east boundary $(y=200 \mathrm{~km})$, beyond which the temperature follows the 40-Myr oceanic lithosphere geotherm. The Great Valley keeps 50 Myr geotherms.

The model (Fig.2c) shows that formation of a shear band near the southmost edge of the Great Valley as in Model 2. The northeast-dipping faultappears at the southern SAF ( $x$ > $430 \mathrm{~km})$ while the fault near the Bid Bend $(250 \mathrm{~km}<x<320 \mathrm{~km})$ dips towards the coast area. In-between the northeastand southwestdipping fault segment ( $x=320-430 \mathrm{~km})$, there is a segment of nearly vertical faultplane (Fig. 2c). This is comparable with the first order features of fault dipping pattern in the SAF in the Southern California (Fig. 1).

\section{Discussion}

The numerical models indicate that lower crustal rheology controls the brittle fault dip direction in the setting like the SAF. In the following sections, comprehensive geophysical observations are utilized to infer the in-situ lower crustal rheology in the SAF system.

\subsection{Rheology variation along the SAF}

Model 3 requires higher viscosity of lower crust in the Great Valley than that in the central coast area (the Western Transverse Range), and the viscosity in the south coast range (west to the SAF) is higher than that in Mojave block (close to the San Bernardino Mountains). The seismogenic layer thickness in the crust may reflect the strength of the crust, which is a combination of the effects of temperature, composition, and strain rate.

Generally, the thicker the seismogenic layer, the stronger (higher viscosity) the lower crust 
Center are used to calculate the seismogenic thickness (Hauksson et al., 2012). The reported hypocenterdepth uncertainty is less than $1.25 \mathrm{~km}$ at $90 \%$ confidence. We draw three profiles (P1, P2 and P3 in Fig.1) of $60 \mathrm{~km}$ long across the different segments of the SAF. The SAF is in the midpoint of each profile. Earthquakes with in $20 \mathrm{~km}$ of the selected line are projected to the corresponding profile. For each half section, the seismogenic thickness is defined as a depth above which 95\% of the events are located and marked as D95 (Fig. 3).

The P1 and P3 profiles sample the earthquakes in the SAF segment with moderate dip and show D95 differences between the fault-bounded blocks of more than $5 \mathrm{~km}$ (Fig. 3). In contrast, P2 profile located in the near-vertical segment demonstrates that the contrast of D95 depth for two blocks is less than $1 \mathrm{~km}$ (Fig. 3). Additionally, the D95 in the Great Valley $(20.0 \mathrm{~km})$ is deeper than that to the west $(14.3 \mathrm{~km})$, and the D95 in the San Bernardino Mountains $(13.0 \mathrm{~km})$ is shallower than that to the west of the SAF $(18.2 \mathrm{~km})$. This indicates stronger lower crust in the Great Valley than that in the Western Transvers Range, and that the San Bernardino Mountains may have lower viscosity in the deep crust than the block to the west of the SAF. This is consistent with the rheology requirement in the numerical model to cause the southwest-dipping fault near the Big Bend and northeast-dipping fault to the south most segment.

Topographic swaths $40 \mathrm{~km}$ wide along each of the three sections are compiled to see 211 whether the strain asymmetry is reflected in topography. The asymmetry of seismogenic 212 thickness distribution across the SAF in P1 and P3 is seen in the topography as well (Fig. 213 3). For the median lines in $\mathrm{P} 1$ and $\mathrm{P} 3$, the block of deeper $\mathrm{D} 95$ has about $1500 \mathrm{~m}$ lower 214 elevation than the one of thinner seismogenic thickness, and the P2 profile shows the dif215 ference in topography is less than $500 \mathrm{~m}$ (Fig. 3). The topography difference is potentially a 216 reflection of regional crustal thickness and density variation. We further collect the density 
information in the crystalline crust which is derived from the inversion of residual gravity anomaly that has the influence of sediments and variations in Moho depth removed (Kaban and Mooney, 2001). They found that the density in the Great Valley $\left(3000-3100 \mathrm{~kg} / \mathrm{m}^{3}\right)$ is much higher than that in the Western Transverse Range $\left(<3000 \mathrm{~kg} / \mathrm{m}^{3}\right)$ for the Big Bend area. Since the inversion method only considers anomalies of wavelength larger than 150 $\mathrm{km}$, the horizontal resolution is too limited to distinguish between P2 and P3. For the southern SAF, the first-order observation is that the density in the block located west of SAF (coast side) is about $50 \mathrm{~kg} / \mathrm{m}^{3}$ higher than that in the east block (Mojave side). The density in crystalline crust is a good indicator of bulk crust composition, i.e., higher densities correspond to rheologically stronger, quartz-poor compositions. The high density in the Great Valley has been interpreted to be oceanic in nature, composed of mafic and ultra-mafic rocks (Kaban and Mooney, 2001). The Great Valley functions as a rigid block and almost accommodates no deformation in its interior, as is seen from surface slip field recorded by GPS observations

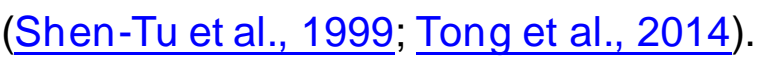

Although material of higher seismic wave velocity does not always correspond to higher viscosity, seismic wave velocity tomography at the comparable depths beneath surface is thought to be a good proxy of strength (viscosity) contrast in the lower crust. High-resolution 234 S wave tomography shows that, at depth of $20 \mathrm{~km}$, the Great Valley and the south coast area has high shear velocity $(4.0-4.2 \mathrm{~km} / \mathrm{s})$ in the region. The corresponding upper plate (i.e., the hanging wall of the transpressional fault), the Western Transverse Range and south Mojave, have the low velocity $(3.4-3.8 \mathrm{~km} / \mathrm{s})$ in the region. The vertical segment that lies inbetween, both sides of the fault are of low velocity (3.4-3.8 km/s) (Lee et al., 2014). The first order features of S wave velocity are also mapped by other seismic studies (Tape et al., 
241 a stronger lower crust in the Great Valley and the south coast area than in the Western

242 Transverse Range and the San Bernardino Mountains, respectively. Such rheology contrast 243 may form the moderately dipping fault in the transpressional environment as observed in 244 our numerical models.

245 The moderately dipping segment at the southern end was suggested to root in shallowly 246 dipping fabrics in the ductile lower crust which was revealed by seismic anisotropic studies 247 (Schulte-Pelkum et al., 2020). This observation does not conflict with our hypothesis. The 248 inherited layered weak zones at the brittle-ductile transitional depth can be a sharp boundary 249 to facilitate the fault-normal movement at the brittle-ductile transitional depth. On the other 250 hand, the seismic anisotropic features can be attributed to or enhanced by the fault-normal 251 movement at the brittle-ductile transitional depth in the Southern California.

\subsection{Depth distribution of earthquakes in Southern California}

We compare the depth variation of earthquake occurrence for four areas in Southem 254 California. Two regions are along the SAF, one close to the Big Bend (Bend in Fig. 4) and 255 the other to the west of the southern SAF (WSAF in Fig. 4). The other two are in the Eastern 256 California Shear zone, one north to the Garlock Fault (NGF in Fig. 4) and the other south to 257 the Garlock Fault (SGF in Fig. 4). With the focal mechanism solution data from Southern 258 California Earthquake Data Center (Yang et al., 2012), we select events with magnitude > 259 1, and divide them in to two groups: one has shallow $\operatorname{dip}\left(<30^{\circ}\right)$ and the other steep $\operatorname{dip}(>$ $26080^{\circ}$ ). The total events are also plotted as a reference.

The total cases and the steep group have a consistent trend of depth distribution, i.e., 262 the peak number of occurrence frequency occurs at depth of 2-10 km, after which it de263 creases with depth (Fig. 4). The shallow dip group shows the same trend for those in the 
264 Eastern California Shear Zone (NGF and SGF in Fig. 4), but different features for those 265 along the SAF where there are moderately dipping fault planes. The maximum in the SAF 266 cases (Bend and WSAF in Fig. 4) occurs at the depth to the base of the seismogenic layer. 267 We note that the total number of earthquakes in the Bend is less than the number of those 268 occurring in SGF, but the number of earthquakes in the shallow group for the Bend at depth > $26910 \mathrm{~km}$ is still larger than that in SGF. That means the shallow cases in the moderately dipping 270 segments of SAF is statistically significant and is not biased by total numbers. The depth 271 variation of earthquakes with steep and shallow dips suggests that the selected seismogenic 272 faults are steeply dipping at depth $<10 \mathrm{~km}$ but may gradually reduce their dip at depth for 273 those in the SAF. This is consistent with the seismic image of the southern SAF near the 274 Salton Sea, which is detected to be near vertical at shallow depth $(<9 \mathrm{~km})$, but dips $\sim 50^{\circ}-$ $27560^{\circ}$ northeast for the deeper part (Fuis et al., 2017). This pattern is also found in our numer276 ical models: the deeper part $(>10 \mathrm{~km})$ is affected by the long-term ductile transpressional 277 deformation, which is initially set to be vertical (Fig. 5). The shallow groups at deeper part in 278 the young fault zone, NGF and SGF, is not as significant as that in the SAF, which is con279 sidered as a mature fault that has evolved for 10's million years. The long-term evolution of 280 the SAF might have been subjected to fault-plane-normal shear stress imparted from the 281 viscous flow moving from the fault-bounded block with high viscosity to the one with low 282 viscosity in a transpressional stress regime. Such fault-plane-normal flow in the lower crust 283 could have forced the fault dip at the brittle-ductile depth to the flow direction.

\section{$284 \quad 5.3$ Garlock Fault}

Our numerical experiments predict formation of a major shearband along the southem boundary of the Great Valley block. The shear band mimics the Garlock fault that intersects 287 the SAF near the Big Bend and may explain its activity. Formation of the Garlock fault is 
debated with three broadly proposed models: (1) extrusion as a conjugate fault of the SAF

(Hill and Dibblee, 1953), (2) transform fault for the Basin and Range extension (Davis and

290 Burchfiel, 1973), (3) rotation of the Mojave block (Guest et al., 2003). Our model suggests 291 that formation of the Garlock fault requires a stronger lower crust in the coast area than the 292 Mojave block (Fig. 5). This has consistentwith both gravity and seismic observations (Kaban 293 and Mooney, 2001; Lee et al., 2014). As the strong Great Valley block moves towards the 294 Mojave block, it is impeded by strong coast area, squeezing out the Mojave block. This is 295 accommodated by the leftlateral Garlock fault (Fig. 2 \& 5). The Garlock fault was thought to 296 begin its sinistral slip ca. $11 \mathrm{Ma}$ (Andrew et al., 2014), and the eastern branch of the Garlock 297 fault might have been related to extension of the Basin and Range and the East Califomia 298 Shear Zone development (Davis and Burchfiel, 1973; Hatem and Dolan, 2018), the effect of 299 which is not considered in our numerical model. Our model supports the extrusion model for 300 the western branch of the Garlock fault. On the other hand, our model suggests the Basin 301 and Range extensions that have weakened the lithospheric strength may be an important 302 'open' boundary to facilitate the extrusion of the Mojave block.

\section{Conclusions}

304 This study focuses on the formation of moderately dipping fault segments of the strike-slip 305 San Andreas fault. 3D numerical models suggest the lower crustal viscosity contrast across 306 the faultplane might have controlled the fault dip direction in a transpressional environment. 307 The fault-normal flow direction in the viscous lower crust near the strike-slip fault plane is 308 from the one with higher viscosity to the one with lower viscosity. The long-term viscous 309 deformation upward reduces the dip angle of the initially near vertical fault plane at the brit310 tle-ductile transition depth. This is consistent with the observations of the moderately dipping 
311 segments of the San Andreas fault: a near-vertical fault plane for shallow depth $(<10 \mathrm{~km})$, 312 and a shallow dip angle at depth $>10 \mathrm{~km}$. The viscosity contrast across the fault plane is 313 consistent with seismogenic thickness variations along the San Andreas fault, and other 314 geophysical observations.

\section{Acknowledgements}

This research was funded by the Australian Research Council through Discovery

318 Grant \#DP170103350 to M. Quigley. H. Yang received the Melbourne Research Schol-

319 arship, the Baragwanath Travel Scholarship, and the Albert Shimmins Writing-Up

320 Award from the University of Melbourne to assist in research development. Geophysi-

321 cal maps are produced by using the Generic Mapping Tools (GMT) package (Wessel

322 et al., 2013).

\section{References}

Anderson, E., 1905. The dynamics of faulting. Transactions of the Edinburgh 325 Geological Society 8, 387-402.

Andrew, J.E., Walker, J.D., Monastero, F.C., 2014. Evolution of the central Garlock 327 fault zone, California: A major sinistral fault embedded in a dextral plate margin. Geological 328 Society of America Bulletin, B31027. 31021.

Atwater, T., Stock, J., 1998. Pacific-North America plate tectonics of the Neogene 330 southwestern United States: an update. International Geology Review 40, 375-402. 
Bowman, D., King, G., Tapponnier, P., 2003. Slip partitioning by elastoplastic 332 propagation of oblique slip at depth. Science 300, 1121-1123.

Braun, J., Beaumont, C., 1995. Three - dimensional numerical experiments of strain 334 partitioning at oblique plate boundaries: Implications for contrasting tectonic styles in the 335 southern Coast Ranges, California, and central South Island, New Zealand. Journal of 336 Geophysical Research:Solid Earth 100, 18059-18074.

Collettini, C., Niemeijer, A., Viti, C., Marone, C., 2009. Fault zone fabric and fault weakness. Nature 462, 907-910.

Davis, G.A., Burchfiel, B.C., 1973. Garlock fault:An intracontinental transform structure, 340 southern California. Geological Society of America Bulletin 84, 1407-1422.

DeMets, C., Dixon, T.H., 1999. New kinematic models for Pacific-North America motion 342 from $3 \mathrm{Ma}$ to present, I: Evidence for steady motion and biases in the NUVEL-1A model. 343 Geophysical Research Letters 26, 1921-1924.

344 Fliedner, M.M., Ruppert, S., Malin,P.E., Park, S.K., Jiracek, G., Phinney, R.A., Saleeby, 345 J.B., Wernicke, B., Clayton, R., Keller, R., Miller, K., Jones, C., Luetgert, J.H., Mooney, W.D., 346 Oliver, H., Klemperer, S.L., Thompson, G.A., 1996. Three-dimensional crustal structure of 347 the southern Sierra Nevada from seismic fan profiles and gravity modeling. Geology 24, $348 \quad 367-370$. 
Fuis, G.S., Bauer, K., Goldman, M.R., Ryberg, T., Langenheim, V.E., Scheirer, D.S., 350 Rymer, M.J., Stock, J.M., Hole, J.A., Catchings, R.D., 2017. Subsurface Geometry of the 351 San Andreas Fault in Southern California: Results from the Salton Seismic Imaging Project 352 (SSIP) and Strong Ground Motion Expectations. Bulletin of the Seismological Society of 353 America.

Fuis, G.S., Ryberg, T., Godfrey, N.J., Okaya, D.A., Murphy, J.M., 2001. Crustal 355 structure and tectonics from the Los Angeles basin to the Mojave Desert, southern Califormia. 356 Geology 29, 15-18.

Fuis, G.S., Scheirer, D.S., Langenheim, V.E., Kohler, M.D., 2012. A New Perspective 358 on the Geometry of the San Andreas Fault in Southern California and Its Relationship to 359 Lithospheric Structure. Bulletin of the Seismological Society of America 102, 236-251.

Glazner, A.F., Walker, J.D., Bartley, J.M., Fletcher, J.M., 2002. Cenozoic evolution of 361 the Mojave block of southern California. Geologic evolution of the Mojave Desert and 362 southwestern Basin and Range: Geological Society of America Memoir 195, 19-41.

Guest, B., Pavlis, T.L., Golding, H., Serpa, L., 2003. Chasing the Garlock: A study of 364 tectonic response to vertical axis rotation. Geology 31, 553-556.

Hatem, A.E., Dolan, J.F., 2018. A model for the initiation, evolution, and controls on 366 seismic behavior of the Garlock fault, California. Geochemistry, Geophysics, Geosystems. 
Hauksson, E., Yang, W.Z., Shearer, P.M., 2012. Waveform Relocated Earthquake 368 Catalog for Southern California (1981 to June 2011). Bulletin of the Seismological Society 369 of America 102, 2239-2244.

Hill, M.L., Dibblee, T.W., 1953. San Andreas, Garlock, and Big Pine Faults, California 371 - a Study of the Character, History, and Tectonic Significance of Their Displacements. 372 Geological Society of America Bulletin 64, 443-\&. Jones, C.H., Kanamori, H., Roecker, S.W., 1994. Missing roots and mantle "drips": 374 Regional Pn and teleseismic arrival times in the southern Sierra Nevada and vicinity, 375 California. Journal of Geophysical Research: Solid Earth 99, 4567-4601.

Kaban, M.K., Mooney, W.D., 2001. Density structure of the lithosphere in the 377 southwestern United States and its tectonic significance. J Geophys Res-Sol Ea 106, 721 378739

Karato, S.I., Jung, H., 2003. Effects of pressure on high -temperature dislocation creep 380 in olivine. Philosophical Magazine 83, 401-414.

Kim, W., Hong, T.K., Lee, J., Taira, T., 2016. Seismicity and fault geometry of the San 382 Andreas fault around Parkfield, California and their implications. Tectonophysics 677, 34 38344. 
Koons, P.O., Norris, R.J., Craw, D., Cooper, A.F., 2003. Influence of exhumation on 385 the structural evolution of transpressional plate boundaries: An example from the Southern 386 Alps, New Zealand. Geology 31, 3-6.

Lee, E.J., Chen, P., 2017. Subsurface fault geometries in Southern California 388 illuminated through Full-3D Seismic Waveform Tomography (F3DT). Tectonophysics 703, $389 \quad 42-49$.

390 Lee, E.J., Chen, P., Jordan, T.H., Maechling, P.B., Denolle, M.A.M., Beroza, G.C., 391 2014. Full-3-D tomography for crustal structure in Southern California based on the 392 scattering-integral and the adjoint-wavefield methods. J Geophys Res-Sol Ea 119, 64213936451.

Lin, G.Q., Shearer, P.M., Hauksson, E., 2007. Applying a three-dimensional velocity 395 model, waveform cross correlation, and cluster analysis to locate southern Califomia 396 seismicity from 1981 to 2005. J Geophys Res-Sol Ea 112. system: Effects of elastic heterogeneity and fault geometry. J Geophys Res-Sol Ea 118, 399 689-697. 401 Andreas fault gouge from SAFOD core. Nature 472, 82-85. 
Manley, C.R., Glazner, A.F., Farmer, G.L., 2000. Timing of volcanism in the Sierra 403 Nevada of California: Evidence for Pliocene delamination of the batholithic root? Geology $40428,811-814$.

Mansour, J., Giordani, J., Moresi, L., Beucher, R., Kaluza, O., Velic, M., Farrington, 406 R.J., Quenette, S., Beall, A.P., 2020. Underworld2: Python geodynamics modelling for 407 desktop, hpc and cloud. Journal of Open Source Software 5, 1797.

Meade, B.J., Hager, B.H., 2005. Block models of crustal motion in southern Califomia 409 constrained by GPS measurements. J Geophys Res-Sol Ea 110.

Mooney, W.D., Weaver, C.S., 1989. Regional crustal structure and tectonics of the 411 Pacific coastal states; California, Oregon, and Washington. Geological Society of America 412 Memoirs 172, 129-162.

Moresi, L., Quenette, S., Lemiale, V., Meriaux, C., Appelbe, B., Mühlhaus,H.-B., 2007. 414 Computational approaches to studying non-lineardynamics of the crust and mantle. Physics 415 of the Earth and Planetary Interiors 163, 69-82.

416 Niemi, N.A., Buscher, J.T., Spotila, J.A., House, M.A., Kelley, S.A., 2013. Insights from 417 low-temperature thermochronometry into transpressional deformation and crustal 418 exhumation along the San Andreas fault in the western Transverse Ranges, California. 419 Tectonics 32, 1602-1622. 
Plesch, A., Shaw, J.H., Benson, C., Bryant, W.A., Carena, S., Cooke, M., Dolan, J., 421 Fuis, G., Gath, E., Grant, L., Hauksson, E., Jordan, T., Kamerling, M., Legg, M., Lindvall, S., 422 Magistrale, H., Nicholson, C., Niemi, N., Oskin, M., Perry, S., Planansky, G., Rockwell, T., 423 Shearer, P., Sorlien, C., Suss, M.P., Suppe, J., Treiman, J., Yeats, R., 2007. Community 424 fault model (CFM) for southern California. Bulletin of the Seismological Society of America $42597,1793-1802$.

Popov, A.A., Sobolev, S.V., Zoback, M.D., 2012. Modeling evolution of the San 427 Andreas Fault system in northern and central California. Geochem Geophy Geosy 13, n/a$428 \mathrm{n} / \mathrm{a}$.

Ranalli, G., 1995. Rheology of the Earth. Springer Science \& Business Media.

Roy, M., Royden, L.H., 2000a. Crustal rheology and faulting at strike - slip plate 431 boundaries: 1. An analytic model. Journal of Geophysical Research: Solid Earth 105, 55834325597.

Roy, M., Royden, L.H., 2000b. Crustal rheology and faulting at strike - slip plate 434 boundaries:2. Effects of lower crustal flow. Journal of Geophysical Research: Solid Earth $435105,5599-5613$.

Schulte-Pelkum, V., Ross, Z.E., Mueller, K., Ben-Zion, Y., 2020. Tectonic Inheritance 437 With Dipping Faults and Deformation Fabric in the Brittle and Ductile Southern California 438 Crust. J Geophys Res-Sol Ea 125, e2020JB019525. 
440 United States determined from Quaternary fault slip rates and recent geodetic data. $J$ 441 Geophys Res-Sol Ea 104, 28927-28955.

Tape, C., Liu, Q., Maggi, A., Tromp, J., 2009. Adjoint tomography of the southem 443 California crust. Science 325, 988-992.

444 Tape, C., Liu, Q.Y., Maggi, A., Tromp, J., 2010. Seismic tomography of the southem 445 California crust based on spectral-element and adjoint methods. Geophysical Journal 446 International 180, 433-462.

Tong, X.P., Smith - Konter, B., Sandwell, D.T., 2014. Is there a discrepancy between 448 geological and geodetic slip rates along the San Andreas Fault system? Journal of 449 Geophysical Research: Solid Earth 119, 2518-2538.

Wessel, P., Smith, W., Scharroo, R., Luis, J., Wobbe, F., 2013. Generic mapping tools: 451 improved version released. Eos, Transactions American Geophysical Union 94, 409-410. A case study of the Baikal Rift Zone. Earth and Planetary Science Letters 482, 501-509. 455 shear zones. Earth and Planetary Science Letters 530, 115906. 

457 focal mechanisms for southern California (1981-2010): Temporal stability of the style of 458 faulting. Bulletin of the Seismological Society of America 102, 1179-1194.

459 Zhu, L.P., Kanamori, H., 2000. Moho depth variation in southern California from 460 teleseismic receiver functions. J Geophys Res-Sol Ea 105, 2969-2980.

461 Zoback, M.D., Zoback, M.L., Mount, V.S., Suppe, J., Eaton, J.P., Healy, J.H., 462 Oppenheimer, D., Reasenberg, P., Jones, L., Raleigh, C.B., Wong, I.G., Scotti, O., 463 Wentworth, C., 1987. New evidence on the state of stress of the san andreas fault system. 464 Science 238, 1105-1111. 
Figures
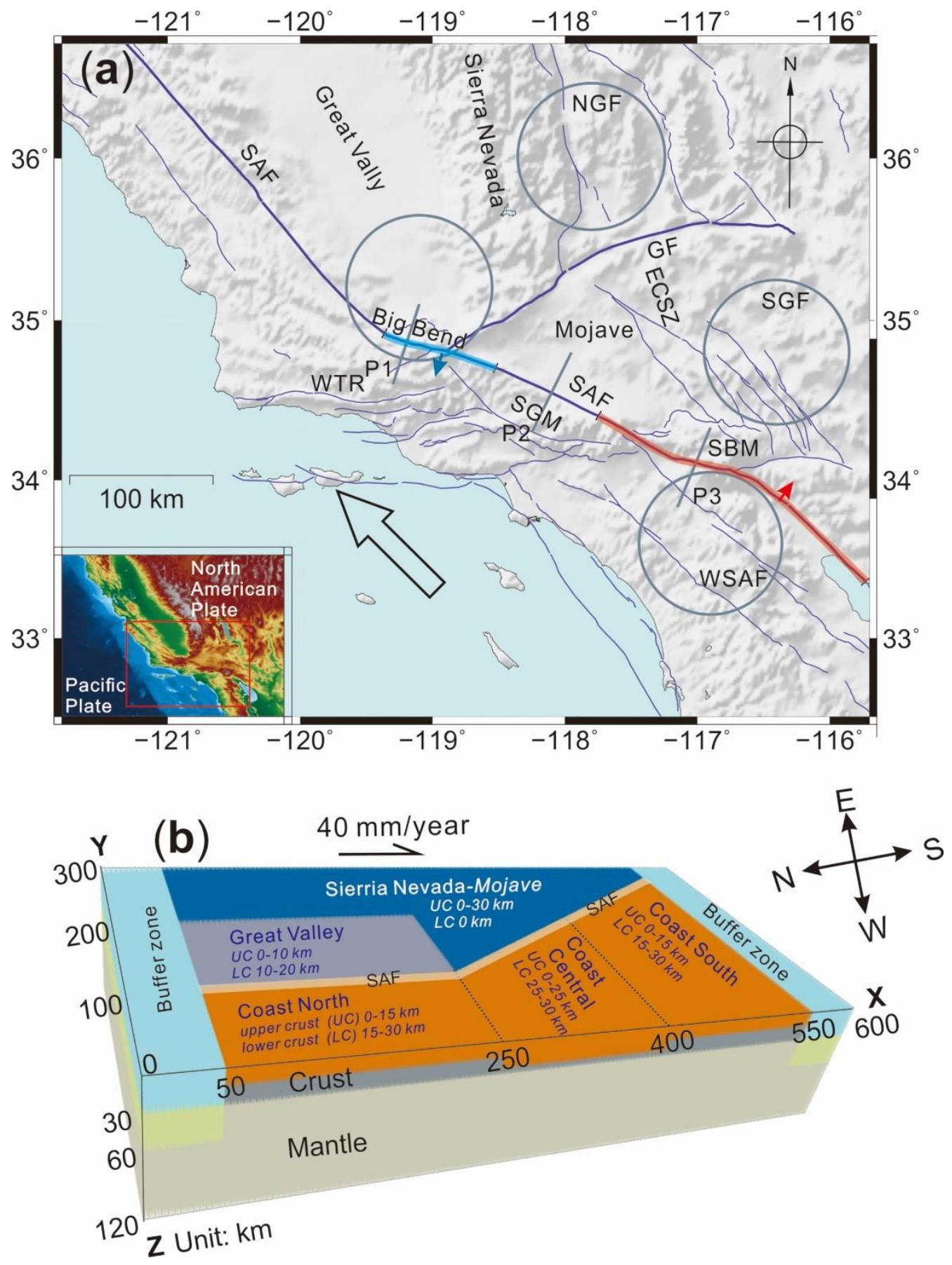

Figure 1. Tectonic settings of the San Andreas Fault system (a) and the simplified numerical

470 model setup (b). (a) Major faults (thick purple lines) including the San Andreas fault (SAF)

471 and the Garlock fault (GF) and other sub-major faults (thin purple lines) are marked on

472 shaded relief map. The arrow shows relative motion between the Pacific Plate and the North

473 American Plate. Along the SAF, the southwest dipping fault segment near the Big Bend is 
474 coded as blue color while the northeast dipping segment in the southern end is denoted by 475 red color. Abbreviations for some main structures: SGM, San Gabriel mountain; SBM, San 476 Bernardino mountain; ECSZ, Eastern California Shear zone. WTR, Western Transverse 477 Range. The position of three profiles, P1, P2 and P3, shown in Figure 3 is marked by grey 478 lines. Four grey circles with a radius of $50 \mathrm{~km}$ show the area of the sampled earthquakes in 479 Figure 4. (b) The corresponding three-dimensional structure for the Model 3, and the details 480 of other models are stated in the context when used. The constant velocity $40 \mathrm{~mm} \mathrm{yr}^{-1}$ to481 wards the positive $x$ direction is applied on the back vertical plane $(y=300 \mathrm{~km})$ while the 482 velocity in $x$ direction in the front vertical plane $(y=0 \mathrm{~km})$ is zero. Materials are not allowed 483 to move out in the box, and free slip is applied for other velocity components. 

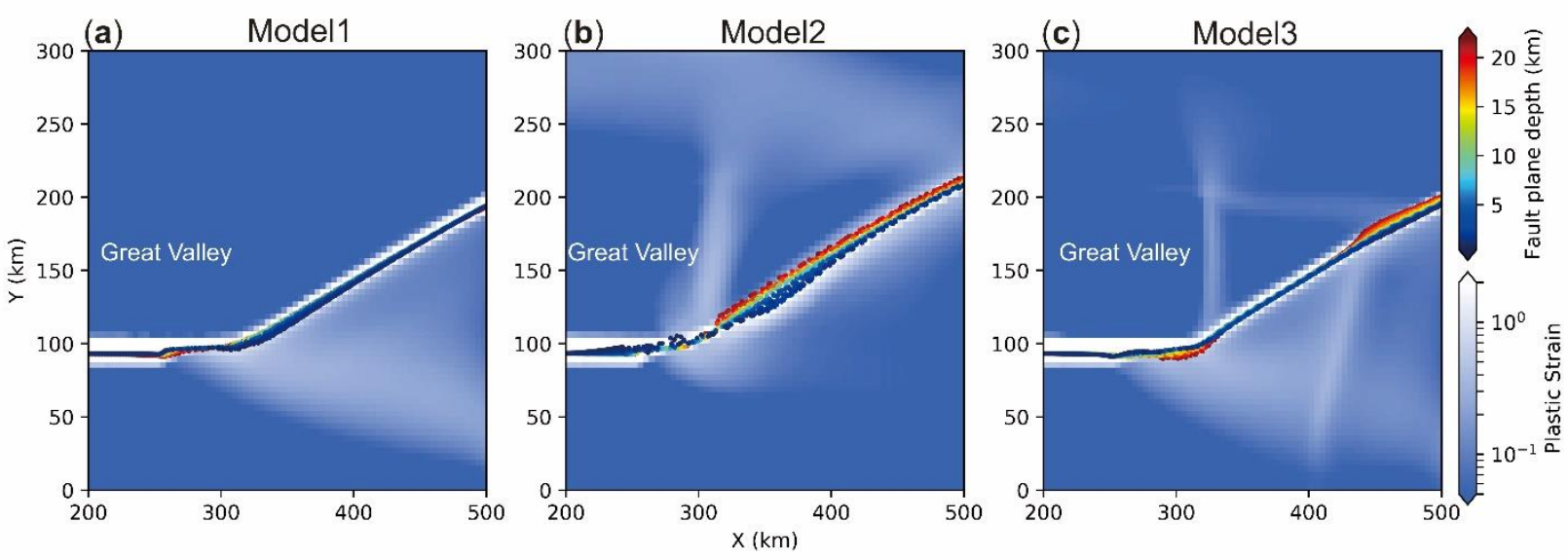

488 Figure 2. Snapshots of plastic strain distribution at depth of $5 \mathrm{~km}$ and the fault plane depth 489 distribution after models running 2.1 Myr for Model 1 (a), Model 2 (b) and Model 3 (c), re490 spectively. Localized shear bends along the right edge of the Great Valley happen to the 491 Model 2 and Model 3. The initially vertical fault planes in Model 2 and Model 3 evolve to be 492 at a moderately dip ( $\left.60^{\circ}\right)$, while the Model 1 of a homogenous crustal property keeps the 493 nearly vertical fault plane. The Model 3 with lateral viscosity variations in the lower crust 494 produces the comparable features of the fault dipping direction variation along the SAF. 495 496 


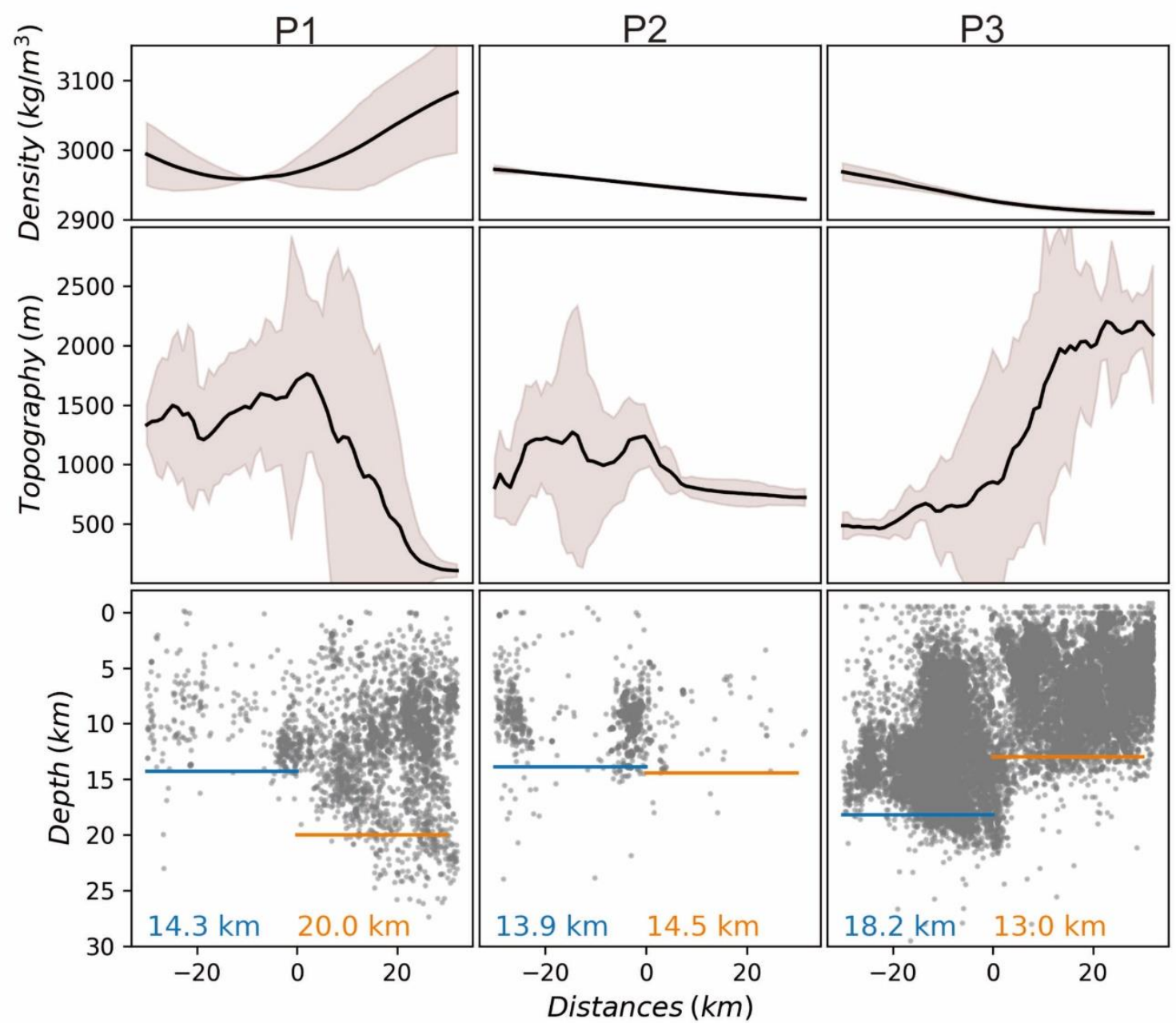

498

499 Figure 3. The density of the crystalline basement layer (upper panel), topography of

500 the earth surface (middle panel) and the earthquake depths (lower panel) distributions

501 along three profiles, P1, P2 and P3 (position marked in Figure 1). All these properties

502 are projected from distances $<20 \mathrm{~km}$ to the corresponding profile. The light red color

503 patches for density and topography show the envelope of the data range, and the black

504 line is the median value. The lines in lower panel marks the D95 depth, above which

$50595 \%$ of the earthquakes are located, for either block that is separated by the fault. The 
506 SAF is located at the mid-point of the profile (distance $=0$ ); all profiles start from south 507 with negative coordinates.

508 

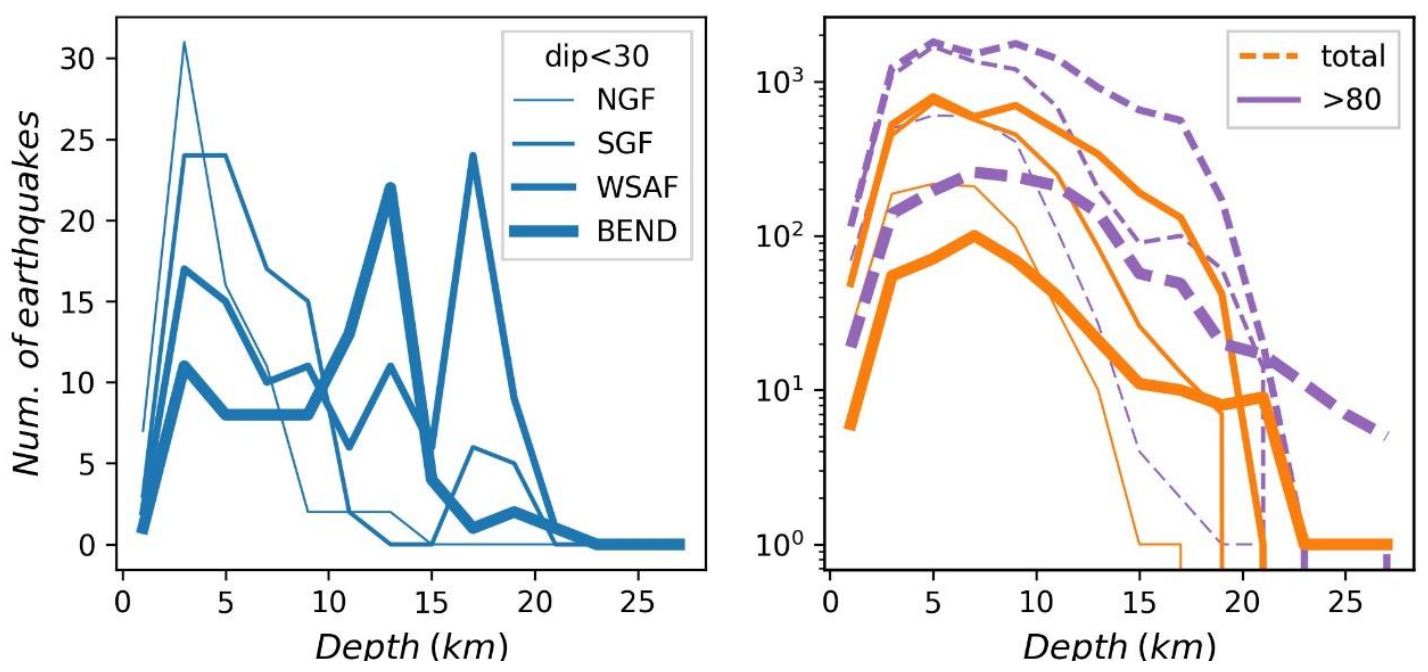

510 Figure 4. The depth distribution earthquakes in four areas (marked as circles in Figure

511 1). The NGF and SGF are sampled from north and south of the Garlock fault, respec-

512 tively. The WSAF is located west of the SAF and BEND is closed to the Big Bend. The 513 events are divided into two group: steep dip $\left(>80^{\circ}\right)$ and shallow dip $\left(<30^{\circ}\right)$, and the to-

514 tal events are also plot as a reference. The steep group shows the peak numbers of 515 earthquakes appear at depth of $2-10 \mathrm{~km}$, but this trend in shallow group is only true for 516 those in NGF and SGF. For the shallow group, the peak number in WSAF and BEND 517 appears at the base of the seismogenic layers $(12-20 \mathrm{~km})$ 

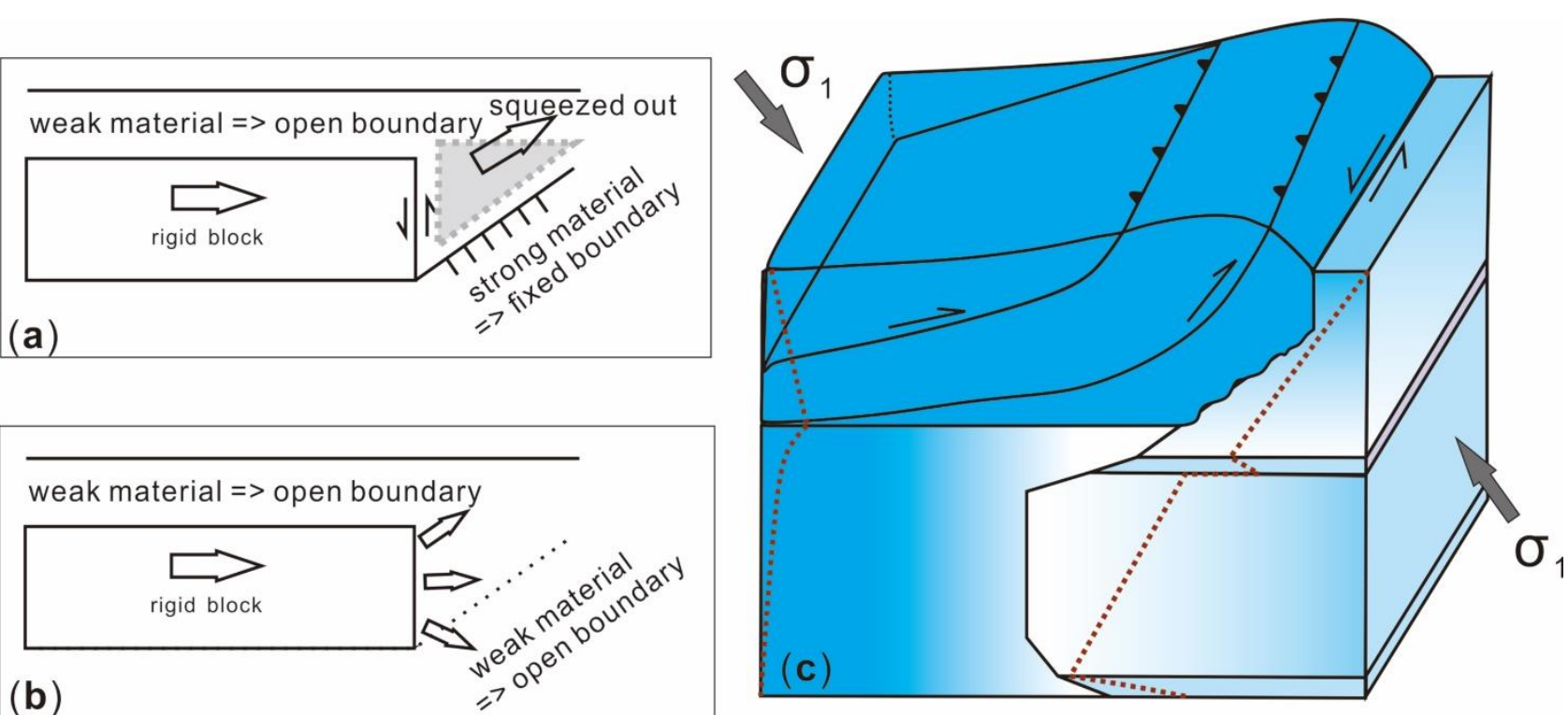

(c)

Figure 5. Sketch model describing how the lower crustal strength distribution affects regional structure development. (a) A strong lower crust in the coast area of the Southem

521 California impedes the Mojave block moving southwest, and the Garlock Fault is formed to 522 accommodate the eastward escape of the Mojave block. (b) A weak lower crust in the coast 523 area tends to produce a diffusive deformation at the right edge of the Great Valley. (c) In a 524 transpressional environment, strong viscous lower crust tends to wedge into the weaker one 525 while the upper crust overlying a weak lower crust over thrust to the one with strong lower 526 crust. Therefore, the deep part of the originally vertical fault plane gradually evolves to be a 527 moderately dipping fault plane, the direction of which is consistent with the flow direction in 528 the lower crust. The red dashed lines stand for scaled strength profile of corresponding block. 


\section{Tables}

532 Table 1. Model parameters: The power law dislocation creep is in viscous regime is described as

$533 \dot{\varepsilon}=A \sigma^{n} \exp \left(-\frac{E+V P}{R T}\right)$ where $\dot{\varepsilon}$ is strain rate, $A$ material constant, $\sigma$ deviatoric stress, $n$ stress ex-

534 ponent, $E$ activation energy, $V$ activation volume, $R$ the gas constant, and $T$ temperature. The ef-

535 fective ductile viscosity $\eta=\frac{\sigma_{\mathrm{II}}}{2 \varepsilon_{\mathrm{II}}}$, where subscript marks the second invariant. Density $\rho=\rho_{o}[1-$ $\left.536 \alpha\left(T-T_{0}\right)\right], \rho_{0}$ is the standard density at $P_{O}=0.1 \mathrm{MPa}$ and $T_{0}=273 \mathrm{~K} ; C p$ is heat capacity. $\alpha$ is

537 thermal expansion. $k$ is heat conductivity, and $H_{r}$ radioactive heat production.

\begin{tabular}{|c|c|c|c|}
\hline & ${\text { Upper } \text { crust }^{[1]}}^{[1]}$ & 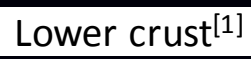 & Mantle $\mathrm{e}^{[2]}$ \\
\hline $\begin{array}{l}A\left(\mathrm{MPa}^{-\mathrm{n}} \mathrm{S}^{-}\right. \\
\left.{ }^{-}\right)\end{array}$ & $3.2 \times 10^{-4}$ & $3.3 \times 10^{-4}$ & $1.3 \times 10^{6}$ \\
\hline$n$ & 2.3 & 3.2 & 3.0 \\
\hline$E \mathrm{~kJ} / \mathrm{mol}$ & 154 & 240 & 510 \\
\hline$V\left(\mathrm{~cm}^{3} / \mathrm{mol}\right)$ & 0 & 0 & 14 \\
\hline$\rho_{o}\left(\mathrm{~kg} / \mathrm{m}^{3}\right)$ & 2700 & 2900 & 3300 \\
\hline$C p(\mathrm{~J} / \mathrm{kg})$ & 1200 & 1200 & 1200 \\
\hline$\alpha\left(\mathrm{K}^{-1}\right)$ & $3 \times 10^{-5}$ & $3 \times 10^{-5}$ & $3 \times 10^{-5}$ \\
\hline$k(\mathrm{~W} / \mathrm{mK})^{[3]}$ & 2.5 & 3 & 3.5 \\
\hline$H_{r}\left(\mu \mathrm{W} / \mathrm{m}^{3}\right)$ & 2 & 0.1 & 0.01 \\
\hline
\end{tabular}

538

[1] Ranalli (1995); [2] Karato and Jung (2003). 